\title{
Theosis as the Unity of Life and Death
}

\author{
Damien Casey \\ Australian Catholic University, Brisbane, Australia \\ Damien.Casey@acu.edu.au
}

\section{Summary}

This paper explores the unity of life and death through the theology of theosis. Drawing on the theologies of Irenaeus and Gregory of Nyssa this paper argues that the doctrine of theosis offers us a holistic theology that is relevant for how we live our lives, restoring a "catholicity" to Latin theology by grounding it within the mystery of the incarnation as a whole. It explores Irenaeus' understanding of the historical development of humanity as part of the necessary process of growth and maturation in our progress towards God. Gregory of Nyssa then takes Irenaeus' understanding of theosis further by arguing for a continuity between this life and the next through his endless 'stretching out' - epektasis - of a limited being to participation in the infinity of the divine, thereby establishing the unity of ontology and morality.

\section{Keywords}

theology of theosis - Irenaeus - Gregory of Nyssa

The unity of life and death, I will argue, can be found in the theology of theosis. Drawing on the theologies of Irenaeus and Gregory of Nyssa I will argue that the doctrine of theosis offers us a holistic theology that is relevant for how we live our lives. Until recently, Latin theology has been fractured, with little relationship between its various branches: between the theology of creation, soteriology, eschatology, moral theology. The rediscovery of the theology of theosis, not only within the Greek tradition but with the Latin tradition itself, provides an opportunity to restore a unity - dare I say "catholicity" - to Latin theology by grounding it within the mystery of the incarnation as a whole. Although the liturgy of the Roman rite is generally holistic in its contemplation of the 
paschal mystery, being is inclusive of the whole mystery of the incarnation and the drama of salvation, popular Latin theology, and especially soteriology, has focussed almost exclusively on the cross, especially as understood by the doctrine of atonement. This doctrine, however, tells us very little about how we should live. ${ }^{1}$ Easter often seems like an afterthought and yet, "if Christ has not been raised, your faith is futile; you are still in your sins" (1 Cor 15:17). To restore a unity to Christian experience and theology, it would seem advisable to return to its source in the Easter experience. Although one cannot talk of the theosis of Jesus as such, it is nonetheless in that foundational experience that the divinisation of humanity is revealed (which in Jesus' case took place at his conception when the eternal Word united itself to our humanity).

All Christian theology flows from reflection on its source in the Easter experience. Those who encountered the Risen Christ experienced the sort of forgiveness and reconciliation, wholeness and peace that only God can offer. The reign of God that Jesus proclaimed in his earthly ministry had become fully realised in the risen Christ and the proclaimer became the proclaimed. And yet, while they experienced Jesus as being in the realm of the divine - in God and of God - he was still recognisable as the man they knew. There is a fundamental continuity between his ministry and his exaltation. This is significant. His uniqueness was not swallowed up in the great ocean of the divine but preserved. The risen Christ still bears the wounds of his crucifixion. His humanity was not compromised through its identity with God but raised to its highest level.

Also central to the Easter experience was the conviction that the fullness of life that Jesus now enjoyed in God was also being offered to us. The hope to which the Easter experience gave rise came to be expressed in a variety of ways according to whatever conceptual apparatus was available. In the New Testament it came to be expressed in a plurality of symbols: as a banquet (Lk 14:15-24); a wedding feast (Mt 22:1-14; 25:1-13); the new Jerusalem "prepared as a bride dressed for her husband" (Rev 21:2); or as the beatific vision as a face to face encounter in which "I shall know just as fully as I am myself known" (1 Cor 13:12). None of these images exhausts the content of that hope. In fact, it would seem that no New Testament image can serve to stand for the whole. To take just a single, albeit the most influential Christian author, St Paul uses metaphor

1 Although it can be interpreted morally in terms of self-sacrifice and being for others, but to do so one is interpreting it in light of a more fundamental idea be it love or service. 
after metaphor in trying to explain the significance of what Christ has achieved for us in his death and resurrection. He uses models such as justification (Rom 3:24-26), Christ as our Paschal lamb (1 Cor 5:7), ransom (Gal 3:13) and scapegoat (2 Cor $5: 21$ ). None of these models is actually consistent with the other. Paul clearly like cultic metaphors as he uses them to refer to his own "priestly service (Rom 15:16), his "being poured out as libation" (Phil 2:17), of a gift sent to him as "a fragrant offering" (Phil 4:18) and of Christian life as a "living sacrifice" (Rom 12:1).

The nature of our salvation is unable to be captured in a definitive way because ultimately it is God who is our salvation. It is a thoroughly eschatological reality that defies all attempts to define or capture it within a system, but for some reason, in Latin Christianity, the substitution theory of atonement has come for many to stand for this whole mystery. Previously, ransom theory had held sway, but whereas previously it had been the devil who had demanded payment of the debt, Anselm inverted it so that now God is the one who legitimately exacts the payment. There is much to critique in the legalistic juridical model but I will content myself with one criticism. This model does not sit well with Jesus' insistence on cancelling the debt as a fundamental aspect of Christian practice (Cf. Mt 18:22).

Apart from the observation that it was for our salvation that Christ became incarnate, it is worth noting that the Christological debates of the fourth and fifth centuries were not at all concerned the mechanism of salvation. Rather they were concerned with the agent of our salvation. What was at stake is encapsulated by two axioms: the first by Athanasius of Alexandria who, in defending the full divinity of Christ, asserted that "the Son of God became human so that we might become God;" ${ }^{2}$ the second by Gregory Nazianzen who in arguing for the full humanity of Christ insisted that "What has not been assumed has not been healed."3 Theosis, in other words, is at the heart of it. And the theory of theosis restores a unity to the Christian life and death.

\section{$2 \quad$ Theosis in Irenaeus}

The use of the distinct term theosis by Christians, as opposed to the term "apotheosis" as used by the Greek philosophers, suggests a deliberate distancing from pagan connotations. Irenaeus was the theologian who developed the

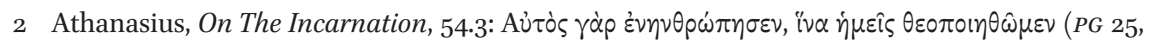
col. 192B. Trans. by J. Behr, Crestwood, NY, 2011, p. 167).

3 Gregory Nazianzen, Letter 101.32, to Cledonius (Grégoire de Nazianze, Lettres théologiques, ed. P. Gallay (sc, 208), Paris, 1974, pp. 36-68). 
notion most from its scriptural basis and establishing the contours of Theosis theory linking creation, salvation and eschatology. According to Irenaeus, the historical development of humanity was intended by God from the beginning, not as a fall from some static eternal state of perfection or contemplation, but as part of the necessary process of growth and maturation. And so Irenaeus argues that God could have endowed humanity with perfection from the beginning but that we would not have been able to receive it. ${ }^{4}$

The growth and development of humanity nourished by the Spirit and fulfilled in the Son, is a growth towards the perfection of God. The sin of Adam is not the catastrophe that it is for atonement as the sin of Adam and Eve was one of immaturity rather than malice. The incarnation was not a remedy for the Fall, as Irenaeus believed that it was always God's intention to become human in order that humanity might have full communion with the divine.

The ideal, therefore, is not to be found in some legal template, established in the beginning and which Adam transgressed. If the incarnation is merely a remedy for transgression, then the divine remains intrinsically foreign to the world and an intervention of the last resort. What it is to be human is not revealed in human nature, as a simplistic understanding of natural law would have it, but in what we are called to become. It is not Adam who is the paradigm of our humanity but Christ who is the sum and completion of all human history and who reveals to us our own divine destiny. Humanity is created good, but not yet complete, perfectible, not yet perfect.

Now it is of the nature of God's intended gift to humanity to share in God's own life that it could not be received complete and whole. Humanity needed to grow in order to receive it. ${ }^{5}$ Adam's mistake was trying to grasp what could only be given and graciously received. As James Alison explains:

One of the things revealed by the doctrine of original sin is that it is our capacity to receive gratuitously that was damaged in the fall: not our

4 "God had power at the beginning to grant perfection to man; but as the latter was only recently created, he could not possibly have received it, or even if he had received it, could he have contained it, or containing it, could he have retained it": Irenaeus, Adv. Haer. 4.38.2, in: PG 7a, col. 1107 A. Trans. by A. Roberts and J. Donaldson, in: The Ante-Nicene Fathers, vol. 1, Grand Rapids, Mich., 1956, pp. 315-556. This translation of Adv. Haer. is cited throughout this paper.

5 "Now it was necessary that man should in the first instance be created; and having been created, should receive growth; and having received growth, should be strengthened; and having been strengthened, should abound; and having abounded, should recover; and having recovered, should be glorified; and being glorified, should see his Lord." Irenaeus, Adv. Haer. 4.38.3; $P G$ 7a, col. 1108C. 
capacity to receive, because we have to receive in order to exist, but our capacity to receive gratuitously, which is the only way we can ever share in divine life, because that life can never be other than gratuitous.

One needs to wait patiently for the appropriate time according to the will of the Creator. This necessary patience Irenaeus contrasts with the haste which he considers to be the characteristic error of the Gnostics. And so Irenaeus asks "How, then, shall he be a God, who has not as yet been made a man? Or how can he be perfect who was but lately created?"6 Rather, we should wait upon the hand of our maker to finish the work, offering God our "heart in a soft and tractable state" so that God may bring us to perfection. ${ }^{7}$

What Christ restores to us in the incarnation is the capacity to receive and to grow in the likeness of God that was damaged in the fall. ${ }^{8}$ But he does so, in Irenaeus' view, not simply by becoming human, or performing a single saving act, but by entering wholly into the human condition, 9 "by entering into the flow of time" and "waiting on God for his own increase."10

He therefore passed through every age, becoming an infant for infants, thus sanctifying infants; a child for children, thus sanctifying those who are of this age, being at the same time made to them an example of piety, righteousness, and submission; a youth for youths, becoming an example to youths, and thus sanctifying them for the Lord. So likewise He was an old man for old men ... sanctifying at the same time the aged also, and becoming an example to them likewise. Then, at last, He came on to

Adv. Haer. 4.39.2; $P G$ 7a, col. $1110 \mathrm{~B}$.

$7 \quad$ Adv. Haer. 4.39.2; $P G$ 7a, col. 1110C.

8 "He commenced afresh the long line of human beings, and furnished us, in a brief, comprehensive manner, with salvation; so that what we had lost in Adam-namely, to be according to the image and likeness of God-that we might recover in Christ Jesus." Adv. Haer. 3.18.1.

"He therefore passed through every age, becoming an infant for infants, thus sanctifying infants; a child for children, thus sanctifying those who are of this age, being at the same time made to them an example of piety, righteousness, and submission; ... Then, at last, He came on to death itself, that He might be 'the first-born from the dead, that in all things He might have the pre-eminence,' the Prince of life, existing before all, and going before all." Adv. Haer. 2.22.4.

10 J. Vogel, "The Haste of Sin, the Slowness of Salvation: An Interpretation of Irenaeus on the Fall and Redemption," Anglican Theological Review 89.3 (2007), pp. 443-459, here pp. 451$45^{2}$. 
death itself, that He might be "the first-born from the dead, that in all things He might have the pre-eminence. ${ }^{11}$

"With him [sc. the Son], nothing is incomplete or out of due season, ... but the Son works them out at the proper time in perfect order and sequence." ${ }^{2}$ Hans Urs von Balthasar puts it succinctly:

God intended man to have all good, but in ... God's time; and therefore all disobedience, all sin, consists essentially in breaking out of time. Hence the restoration of order by the Son of God had to be the annulment of that premature snatching at knowledge, the beating down of the hand outstretched toward eternity, the repentant return from a false, swift transfer into eternity to a true, slow confinement in time. ${ }^{13}$

In waiting upon God, Christ is able to receive the full possession of the Spirit. "The Lord, receiving this as a gift from his Father does himself also confer it upon those who are partakers of himself, sending the Holy Spirit upon all the earth." ${ }^{14}$ One advantage of this approach is that it explains the delay of the parousia - what Christ restores in our salvation is our capacity to learn and to grow in the Spirit. Divinisation requires patience, and waiting for the appropriate time. "But we do now receive a certain portion of his Spirit, tending towards perfection, and preparing us for incorruption, being little by little accustomed to receive and bear God."15 This is not a process that will ever be complete.

For as God is always the same, so the human person in God will always progress towards God. God will never cease to benefit and enrich the human person, and the human person will never cease from receiving benefit and enrichment from God. ${ }^{16}$

There is for Irenaeus continuity between creation and salvation. Creation itself is the first salvific act.

\footnotetext{
$11 \quad$ Adv. Haer. 2.22.4.

12 Adv. Haer. 3.16.7; PG 7a, col. 926A.

13 H.U. von Balthasar, $A$ Theology of History, San Francisco, Calif., 1994, p. 37. I have kept the gender exclusive language of the original.

14 Adv. Haer. 3.17.2; PG 7a, col. 930B.

15 Adv. Haer. 5.8.1; PG 7b, col. 1142C.

16 Adv. Haer. 4.11.2; $P G$ 7a, col. 1002AB.
} 


\section{Gregory of Nyssa Unites Being and Becoming}

But to give creation its integrity such that it is not something sprung fully formed from the head of Zeus, we must confront the ghost of Plato, namely, the idea that becoming is somehow a fall from perfection. Beyond the veil represented by the death of this mortal body, what is the status of becoming? Is there continuity or a radical discontinuity between this life and the next? Thomas Aquinas, who we may consider to be broadly representative of the Latin tradition, in discussing the perfection of the angels expresses his repugnance at the thought that there could be any growth or progress beyond that veil. ${ }^{17}$ Aquinas is here consistent with the Platonic tradition which sees perfection in virtue as a static achievement. His dominant metaphor for the life in God is, therefore, the Beatific Vision.

Gregory Nazianzen, whose vision of the life in God is similarly contemplative, in this Oration argues for discontinuity between this embodied life and the next. 18

Whoever has been permitted to escape by reason and contemplation from matter and this fleshly cloud or veil (whichever it should be called) and to hold communion with God, and be associated, as far as man's nature can attain, with the purest Light, blessed is he, both from his ascent from hence, and for his deification there, which is conferred by true philosophy, and by rising superior to the dualism of matter, through the unity which is perceived in the Trinity.

Gregory of Nyssa on the other hand argues for continuity. Like Irenaeus, Gregory of Nyssa argues that humanity was created in order to take part in divine blessing. For this to happen there must be an affinity.

17 "Merit and progress belong to this present condition of life. But angels are not wayfarers travelling towards beatitude, they are already in possession of beatitude. Consequently the beatified angels can neither merit nor advance in beatitude. I answer that, in every movement the mover's intention is centered upon one determined end, to which he intends to lead the movable subject; because intention looks to the end, to which infinite progress is repugnant." Summa Theologica, I, q.62, a.9. Trans. Fathers of the English Dominican Province, The Summa Theologica of St. Thomas Aquinas, Second and Revised Edition, 1920, <http://www.newadvent.org/summa/1062.htm>.

18 Gregory Nazianzen, Orat. 21.2: Grégoire de Nazianze, Discours 20-23, éd. J. Mossay (sc, 270), Paris, 1980, pp. 113-115. Trans. Schaff, NPNF, ser. 2, vol. 7, Cyril of Jerusalem, Gregory Nazianzen, 270. 
The same necessity requires that in our partaking of God there should be some kinship in the constitution of the partaker with that which is partaken of. Therefore, as the Scripture says, man was made in the image of God; that like, I take it, might be able to see like; and to see God is, as was said above, the life of the soul. ${ }^{19}$

This affinity therefore is something that was always a part of what it is to be human. For Nyssa the grace of participation comes from humanity's very being. "The nature of Man was made precisely in order to be a participant in every good." ${ }^{20}$ This is why resurrection plays so central a role in his thought about the restoration of the human race to its original design. He understands the renewal of humanity as a gift of the resurrection of Christ, beginning in a person's moral life, and consummated in our bodily resurrection from the dead, but also having much deeper implications as a symbol of the restoration of an alienated creation to unity with God. Like Irenaeus, Gregory of Nyssa argues that we receive according to our capacity and as we mature in goodness our capacity increases.

It should be noted, however, that Gregory of Nyssa tends not to use the word theosis, preferring instead to talk of "participation in God." It is also noteworthy that Gregory of Nyssa uses "participation" rather than the Platonic notion of "assimilation" to the divine as used by the Nazianzen in Oration $21 .{ }^{21}$ Comparing the two terms it would seem that being assimilated to the eternal would seem to negate the temporal, whereas the notion of participation would seem to be more respectful of the integrity of the nature of the creature as being created in time.

In explaining the destiny of those children who had died young Gregory of Nyssa explains: ${ }^{22}$

For the infant ... there is a natural delight in its milk, and in its nurse's arms, and in gentle rocking that induces and then sweetens its slumber.

19 Gregory of Nyssa, De Infantibus 3.2: Gregorii Nysseni Opera. Opera dogmaticaminora 3/2, ed. H. Horner, Leiden, 1997, p. 79. Cited by J. McGuckin, "The Strategic Adaptation of Deification in the Cappadocians," in: Partakers of the Divine Nature. The History and Development of Deification in the Christian Tradition, ed. M.J. Christensen and J.A. Wittung, Grand Rapids, Mich., 2008, pp. 95-114, see p. 105 and n. 54. Trans. by W. Moore and H. Austin Wilson, On Infants' Early Deaths, in: NPNF, ser. 2, vol. 5, Buffalo, NY, 1893, p. 376.

20 Treatise on the Making of Man (De opificio hominis) 26; PG 44, col. 184B.

21 See discussion of McGuckin, "The Strategic Adaptation of Deification in the Cappadocians," pp. 106-107.

22 Gregory of Nyssa, De Infantibus 3.3. Trans. in NPNF ser. 2, vol. 5, p. 377. 
Any happiness beyond this the tenderness of its years naturally prevents it from feeling. In the same manner those who in their life here have nourished the forces of their souls by a course of virtue, and have, to use the Apostle's words, had the senses of their minds exercised, will, if they are translated to that life beyond, which is out of the body, proportionately to the condition and the powers they have attained participate in that divine delight; they will have more or they will have less of its riches according to the capacity acquired. But the soul that has never felt the taste of virtue, while it may indeed remain perfectly free from the sufferings which flow from wickedness having never caught the disease of evil at all, does nevertheless in the first instance partake only so far in that life beyond (which consists, according to our previous definition, in the knowing and being in God) as this nursling can receive; until the time comes that it has thriven on the contemplation of the truly Existent as on a congenial diet, and, becoming capable of receiving more, takes at will more from that abundant supply of the truly Existent which is offered. ${ }^{23}$

There is continuity between this life and the next through his endless 'stretching out' - epektasis - of a limited being to participation in the infinity of the divine. Gregory of Nyssa describes the dynamic of participation in God in The Life of Moses thus:

The Divine One is himself the Good (in the primary and proper sense of the word). whose very nature is goodness. This he is and he is so named, and is known by this nature. Since, then, it has not been demonstrated that there is any limit to virtue except evil, and since the Divine does not admit of an opposite, we hold the divine nature to be unlimited and infinite. Certainly whoever pursues true virtue participates in nothing other than God, because he is himself absolute virtue. Since. then. those who know what is good by nature desire participation in it. And since this good has no limit, the participant's desire itself necessarily has no stopping place but stretches out with the limitless. ${ }^{24}$

23 More problematic, however, is Gregory's subsequent discussion of infant mortality in the light of the problem of God's foreknowledge and power raising the question as to why God would let such a thing happen? Gregory's response is to suggest that the death of the child is a mercy on God's part since God knew that the child would grow up to be a sinner.

24 Gregory of Nyssa, The life of Moses, 1.7. Trans. by A. Malherbe and E. Ferguson (New York, 1978), p. 31. 
While many of the earlier Greek Fathers had spoken of participating in God through the grace of the divine Spirit, Gregory of Nyssa, by identifying goodness as one of the essential perfections of God, demolishes the distinction between morality and ontology as a false one. According to Gregory, participation in sanctity was, in fact, participation in true being. The path of the ascetic is the path of theosis. Theosis then is not a posthumous transcending of human nature but a work in progress to increase our capacity to share in the divine life, to give and receive gratuitously and graciously.

Perhaps the style of asceticism as practiced by Gregory and his siblings is not one that would attract many of us today. But there is only one path and that is growth in love. Is not the family as domestic church, the place of our divinisation where our salvation is worked out in laughter and tears, through joy and sorrow where the tension between limitation and transcendence, union and separation, felt most acutely? It requires ongoing negotiation and dialogue as we grow in our capacity to receive in the divine life that Christ has won for us. 